\title{
Follow the money: Resource allocation and academic supremacy among community and university partners in Food Dignity
}

\section{FoodDignity}

\author{
Christine M. Porter ${ }^{a *}$ and Alyssa Wechsler ${ }^{b}$ \\ University of Wyoming
}

Submitted O ctober 27, 2017 / Revised January 26 and February 25, 2018 / Accepted February 26, 2018 /

Published online July 18, 2018

Citation: Porter, C. M., \& Wechsler, A. (2018). Follow the money: Resource allocation and academic supremacy among community and university partners in Food Dignity. Journal of A griculture, Food Systems, and Community D evelopment, 8(Suppl. 1), 63-82. https:/ / doi.org/ 10.5304/ jafscd.2018.08A.006

Copyright (C) 2018 by the Authors. Published by the Lyson Center for Civic Agriculture and Food Systems. Open access under CC BY license.

\begin{abstract}
A guiding principle in participatory action research collaborations is to strive for equity in relations between community and academic project partners. One promising way of assessing equity and power sharing in such partnerships is to trace and analyze financial resource allocation within them. This paper reports and assesses how nearly US $\$ 5$ million in grant funding was allocated and spent between community and academic partners in a research, extension, and education project called Food Dignity in the United States. Findings from
\end{abstract}

a* Corresponding author: Christine M. Porter, Associate Professor and Wyoming Excellence Chair of Community and Public Health; Food Dignity Principal Investigator; Division of Kinesiology \& Health, College of Health Sciences, University of Wyoming; 1000 East University Avenue, D epartment 3196; Laramie, WY 82071 USA; christine.porter@ uwyo.edu

b Alyssa Wechsler, Associate Research Scientist; Food Dignity project coordinator and G rowing Resilience project manager; Division of Kinesiology \& Health, College of Health Sciences; University of Wyoming; 1000 E. University Avenue, D epartment 3196, Laramie, WY, USA; alywex@uwyo.edu this analysis of extensive financial project records include that $36 \%$ of the funding was subawarded to the five community-based organization (CBO) partners, 40\% supported the work of two university partners, and the remaining $24 \%$ was invested in developing and supporting the collaboration of many diverse partners on a wide range of project goals. Staff salary and fringe composed the single largest spending arena, making up about two-thirds of spending for CBOs and collaboration, and half for universities. However, had faculty salaries been paid from the grant, rather than by the partnering universities, then this component would have been

\section{Funding Disclosure}

Food Dignity (http:/ / www.fooddignity.org) was funded by USD A National Institute of Food and Agriculture's Agriculture and Food Research Initiative Competitive G rant no. 2011-68004-30074.

\section{Contributors and Supporting Agencies}

Blue Mountain Associates; Feeding Laramie Valley; Whole Community Project; East New York Farms!; Dig D eep Farms; University of Wyoming, Cornell University, U.S. D epartment of Agriculture National Institute of Food and Agriculture. 
much higher. Indirect costs and support for graduate students were the next-biggest categories in academic budgets, while CBO s received and spent zero dollars in these arenas. Although this project has received a national award for communitycampus partnerships, we find that, even within a narrow lens of an individual community-university partnership, our allocations underinvested in the research expertise, administrative costs, and capacity development needs of the CBO s. Using a wider lens that encompasses the systemic, institutionalized inequities between community-based and university-based partners, we find that we produced and reproduced inequities in our monetary resource allocations in at least four main ways: employment conditions, institutional support, capacity development, and autonomy, including control over funding. We call these systemic inequities academic supremacy and close with several institutional and individual recommendations for how to begin undoing them.

\section{Keywords}

Food D ignity; Participatory Research; Academic Supremacy

\section{Introduction}

A guiding principle in participatory action research is to strive for equity- both in research partnerships and also, usually, in the outcomes of such partnerships. As outlined in community-based participatory research (CBPR) principles, this means facilitating "a collaborative, equitable partnership in all phases of the research, involving an empowering and power-sharing process that attends to social inequalities" (Israel, Eng, Schulz, \& Parker, 2005, pp. 7-8).

O ne promising way of assessing equity and power sharing in such partnerships is to trace financial resource allocation. The allocation and distribution of funding, and the decision-making regarding how that funding should be allocated, may offer an empirically quantifiable indicator of power (in the Foucaultian sense of power being pervasive, circulating, and normalizing (Foucault,

1 The "we" in this paper specifically consists of the co-authors of this paper and, more abstractly, the larger "we" of the many
1972/ 1980; 1975/ 1995)). Another potential benefit of allocation and spending analysis is to illuminate project leaders' hypotheses, or bets, regarding which investments will best help them reach project goals and how well those bets pay off. Finally, if comparable spending data were available across multiple projects, then cross-project analyses of spending and outcomes might help to identify effective grant-spending strategies, benchmark equitable budget allocations in such partnerships, assess associations between partnership equity and project effectiveness, and increase accountability and transparency in publicly funded research. However, to our knowledge, no funded action research collaboration to date has published detailed financial data and analyses about its partnerships, in either the grey or peer-reviewed literature. In this paper, we ${ }^{1}$ offer such financial data and analysis about how we budgeted and spent nearly US\$5 million, mostly over five years, in an action research and education partnership called Food Dignity. We also examine the implications for equity in community-academic research partnerships. In addition, Food Dignity's community-university liaison, who is also the founder of one of the five CBO s partnering in the project, provides commentary and insight on our work from the standpoint of a community partner in two essays published in this issue (Woodsum 2018a, 2018b). As she illustrates, CBOs and university partners often experience the process and outcomes of these allocations very differently.

\section{Literature Review}

We found four peer-reviewed papers that share some empirical data about financial allocation processes or results in community-academic research project collaborations. Each paper presents very different forms of data, each with different goals, as outlined below. We also searched the grey literature but did not find any further additions to this tiny body of work.

One CBPR collaboration team outlines how it successfully apportioned both tasks and money for a cancer-prevention project among five partner

organizational and individual Food Dignity collaborators who participated in allocating and spending this money. 
organizations (G ehlert et al., 2014). The authors describe a four-stage process of outlining the tasks their project would require, assessing the cost of completing each task, deciding which partners would do which tasks, and then drafting the budgets for each organization accordingly. Their goal was "eliminating institutionalized inequalities" (Gehlert et al., 2014, p. 561). They received assistance from their university partner's research office in assessing the costs and renegotiated budgets after tasks were assigned and before reaching a final agreement. The paper does not share financial allocation data but focuses instead on how the budgets were developed as a suggestion for how to allocate funding equitably.

Another paper derives eight lessons from decades of collaborations to improve Native American health, including two specifically regarding financial allocations (Burhansstipanov, Christopher, \& Schumacher, 2005). One of the lessons is to allocate budgets comparably among partner organizations. The authors share one formula used in their partnership where, after first allocating about US $\$ 40,000$ for administrative and data analysis costs to the primary grant-receiving organization, the rest of the funding is allocated equally. (Indirect costs are not mentioned explicitly.) The other financial lesson was to provide salaries, not just stipends, to Tribal partners and staff. The authors chide academics for asking community-based people to volunteer while academic-based people receive salaries, noting "this is inappropriate" (Burhansstipanov et al., 2005, p. 74).

A third paper provides some detailed spending and cost data from a subset of a budget for a collaboration between a university and an Alaska Native community. The collaboration investigated how to disseminate results from genetic research studies (Hoeft et al., 2014). The goal of this academic-authored paper is to "inform budget discussions in community-academic partnerships" (Hoeft et al., 2014, p. 263) by accounting in detail for US\$115,461 in project expenses. This amount represents about $18 \%$ of the US $\$ 632,828$ award (including indirect costs) from the project funder, the National Institutes of Health (NIH) (author calculations from Table 1 in the paper and from the project's public funding record [Ethics of dissemination, 2010]). The largest spending category that the authors report, by far, is on food and travel expenses for project meetings. These totaled $73 \%$ of the reported expense amount, or US\$85,500 (author calculations from Hoeft, p. 226). Another US $\$ 25,238$ was paid to community partners as honorariums. The authors tabulate the cost of academic-based people's time spent on between-meeting communications (email, phone, and mail) as US\$4,825. They do not provide cost estimates for the likely much more substantial investments of academic time in travel and inperson meetings. They also qualitatively list opportunity costs, borne by community and academicbased partners, of participating in the collaboration. The authors note the importance of investing in the time and travel costs for face-to-face meetings in such collaborations, while providing sufficient community compensation for opportunity costs. They also note the importance of striving to shift academic institutional policies to reduce academic opportunity costs by valuing CBPR more.

Finally, a fourth paper assesses budget allocations to academic vs. community partner organizations across 49 CBPR projects funded by the NIH from 2005 to 2012, based on budget justifications submitted with each project proposal (Cain, Theurer, \& Sehgal, 2014). When the authors were not certain of an allocation, they erred on the side of naming budget lines as community rather than as academic. They found that of the US\$139 million in total awarded amount (including direct and indirect costs), $68 \%$ of funds went to academic organizations and $30 \%$ went to community partners, with the remaining $2 \%$ unclear. Half (24) of the projects analyzed included an award or subaward to a CBO partner. Community financial shares were higher, on average, (35\%) in those projects than for $\mathrm{CBO}$ s partners without awards or subawards, who received $22 \%$ of their average total project awards. Within the average project, with US\$2.8 million in funding, the authors also summarized average budget line allocations (e.g., for personnel, travel, indirect costs) for academic and community partners. In the average project, personnel costs represented the largest single budget 
category for both academic and community partners, with $49 \%$ and $65 \%$ allocated for these expenses, respectively. For academic partners, indirect costs represented the second-largest budget category, constituting $43 \%$ of the total average budget; however, indirect costs composed only $7 \%$ of community partners' total budget (author calculations from data in Table 2, Cain et al., 2014, p. 143). ${ }^{2}$

All four of these papers discuss the importance of allocating funding more equitably between community and university partners. All four describe projects in which academic partners, rather than community partners, held and managed the grants. Of this limited empirical literature on the budgeting of community-academic partnerships, the papers by Cain et al. (2014) and Burhansstipanov et al. (2005) provide empirical reference points for actual community vs. academic partner allocations. Even though indirect costs make up a major proportion of funding for university partner research, the paper by Cain et al. (2014) is the only one to discuss indirect costs. Their work especially, and to some extent the paper by Hoeft et al. (2014), also provides some insight into intraproject allocations between expense category lines. G ehlert et al. (2014) is the only paper in this group to suggest a process for matching the scope of work in a project to the appropriate amount of funding.

A larger body of work discusses principles for equitable partnerships between community and academic institutions and individuals, including direct or indirect references to resource allocation specifically (Israel et al., 2005, pp. 7-9; Israel et al., 2003, pp. 59-70). For example, the goal of

\footnotetext{
2 In addition to paying direct costs of a project, some funders also cover "indirect costs" that grantees incur for general operations (e.g., building maintenance or rent, research review board services, internet service, heat) but that are difficult to calculate precisely enough to charge proportionately to a funder as a direct cost. If a funder does agree to pay indirect costs to grantees, it usually does so as a percentage of direct costs awarded. Grant-making foundations commonly pay a $10 \%$ indirect cost rate to grantees, though some pay none. U.S. federal funding agencies, such as the USDA and NIH, pay much higher indirect cost rates to grantee organizations that have individually negotiated an indirect cost rate with the federal government. The average indirect cost rate paid to
}

"democratizing science by valuing communities as equal contributors to the knowledge production process" (Wallerstein \& Duran, 2010, p. S44 could include valuing these contributions in financially equitable terms. However, academic authors have rarely been explicit about their resource-sharing practices. In one rare example of a specific mention of monetary allocations in the literature, it is about stipends paid by academic partners to community-based partners:

The potential for success of CBPR efforts may be enhanced if sufficient funds are allocated to pay stipends for community members' time and to absorb costs associated with their participation, such as child care, transportation, and meal expenses. Some analysts have suggested that community members be compensated for their time at the level of graduate student researchers as a further demonstration of respect for their contributions. (Minkler, Blackwell, Thompson, \& Tamir, 2003, p. 1212)

Since then, approaches that use stipends as a means to pay community-based collaborators have come under fire as inequitable, especially when academic-based collaborators are receiving salaries, as in the Burhansstipanov et al. (2005) paper discussed above.

The professional association CommunityCampus Partnerships for Health (CCPH) mentions resource allocation explicitly in its Principles of Partnership list-namely, that a real partnership "balances power among partners and enables

$\mathrm{NIH}$ awardee organizations is reported to be $53 \%$ (Ledford, 2014). Using the numbers reported in Cain, Theurer, \& Sehgal (2014) for the $49 \mathrm{NIH}$-funded CBPR projects, it appears that the average university received indirect cost rates of $74.4 \%$ (paid on top of their direct cost awards) vs. 7.5\% indirect cost rates paid to community partners (author calculations from data in Table 2, p. 143). The federal agencies generally will negotiate rates only with organizations that hold major amounts (\$10 million or more) in federal funding awards. Recently, they have become more systematic about suggesting a 10\% de minimus indirect cost rate for organizations without a negotiated rate. In addition, exceptions to these rates are published by each agency. 
resources among partners to be shared" (CCPH, n.d.). A subgroup of CCPH's community-based research partners- the Community Network for Research Equity \& Impact (CNREI) - has issued even more explicit guidance about resource allocation and overall equity in the research enterprise. Its agenda envisions not only equitable research partnerships with academic-based researchers, but also "a shared, balanced, and equal ownership stake in the decision-making system for the research enterprise at the federal, state, local and academic levels" (CNREI, 2013, p. 3) and that "community leaders and community-based organizations will be compensated at the same rate of pay for their time and expertise as academic partners" (p. 4). Of all the practices and principles in the literature, this CNREI guide is the most explicit about not only undoing internal financial inequities within projects, but also the institutionalized inequities between community and academic partners in the research enterprise.

This paper makes a significant empirical contribution to this limited literature about financial resource allocations and their implications in community-university research partnerships by analyzing and assessing spending in a communityuniversity collaboration called Food Dignity using an institutional (in)equity lens.

\section{Background and Setting}

One of the policy successes of the now-defunct Community Food Security Coalition was to secure a line of funding from U.S. D epartment of Agriculture's (USDA) National Institute of Food and Agriculture (NIFA) for Community Food Projects, which aim to build community food systems and improving food security. The first annual request for applications (RFA) was in 1996. NIFA appointed Elizabeth Tuckermanty as the program officer for this funding stream. O ver her first decade of overseeing Community Food Projects, Tuckermanty began to wish that more of the extensive experience and wisdom accumulating among community project leaders could be codified and disseminated (personal verbal communication to Porter, 2011). With this in mind, when NIFA was redesigning its Agriculture and Food Research Initiative (AFRI) competitive grants programs, she successfully advocated for and developed an RFA for "Improved Sustainable Food Systems to Reduce Hunger and Food Insecurity D omestically and Globally" whose purpose was to "develop research, education, and extension sustainable programs on local and regional food systems that will increase food security in disadvantaged U.S. communities and create viability in local economies" (USD A NIFA, 2010, pp. 11-12). Proposals were invited for "integrated" projects - that is, projects that blend research, extension, and education. Such projects could be awarded up to US\$5 million over five years, with multiple partners. NIFA expected to fund up to five projects. So that these projects would leverage the expertise of community-based work in these arenas, the RFA noted that "there are many regional and local sustainable food system programs across the country addressing food insecurity by developing small food economies in diverse ways" and required that "applications must explore best practices in these projects" (USD A NIFA, 2010, pp. 12).

When NIFA issued that call in early 2010, Porter was finishing a community nutrition doctorate at Cornell University and had accepted an assistant professor position at the University of Wyoming (UW), to start in the fall. She began drafting a proposal by drawing upon her academic studies and the mentorship of an experienced community organizer in Ithaca, E. Jemila Sequeira. Porter then invited five CBO s to collaborate: Blue Mountain Associates (BMA) in Wind River Indian Reservation; Feeding Laramie Valley (FLV) in Laramie, Wyoming; Whole Community Project (WCP) in Ithaca, New York; East New York Farms! (ENY F) in Brooklyn, New York; and Dig D eep Farms (DDF) in the Bay area of California. These invitations were largely cold-call contacts except for WCP, which Sequeira directed. In issuing these invitations, Porter considered geography (for variation and for travel-related practicality) and diversity of historical and institutional contexts. As described in the series of essays that open this special issue (D aftary-Steel, 2018; Niedeffer, 2018; Porter, Woodsum, \& Hargraves, 2018; Sequeira, 2018; Sutter, 2018; Woodsum, 2018a), leaders of each of the five $\mathrm{CBO}$ s decided to collaborate on 
the Food Dignity project proposal.

Academic collaborators included professors, research staff, and graduate students at UW, which was the primary grant holder, and at Cornell University. Porter also recruited a "think and do" tank called the Center for Popular Research, Education and Policy (C-PREP) to work as a liaison and support between community and academic partners and to assist the CBO s with research.

The final proposed plan included UW issuing subaward contracts to each of these seven partner organizations (ENYF, WCP, BMA, FLV, DDF, Cornell, and C-PREP), who would receive and manage their own budgets and scopes of work. Our two overarching goals, as stated in the proposal, were:

1. Identifying, developing, and evaluating scalable strategies for organizing sustainable community food systems for food security, in collaboration with communities facing food insecurity.

2. Expanding the capacity to catalyze, support, and research sustainable community food systems for food security in cooperative extension, CBO s, citizens living in lowincome communities, and universities.

In June 2010, Porter was in the midst of moving from Ithaca, New York, to Laramie, Wyoming, while the UW research office submitted the team's Food D ignity proposal to NIFA. Then, on a Friday afternoon in mid-September, Tuckermanty called to let her know that Food Dignity, as the "top rated" proposal, would be funded. We were ultimately awarded US\$4,978,700. We started officially in April 2011 and, with two no-cost extensions, officially ended in March 2018.

\section{Methods}

The primary data used in this paper include, for each partner organization, numbers related to budgets as originally laid out in the grant proposal, budgets as actually subawarded to partners, and actual spending recorded via accounting. These data were meticulously maintained throughout the project for practical and technical reasons, which made them readily available for this analysis.

We examined our overall budget allocations to the organizational partners in four main forms: the five-year budgets originally proposed to NIFA in 2010, the revised budgets included in our annual continuation award proposals required by NIFA, our budgets as actually subawarded to each organization, and the financial reports of actual spending provided to UW by each CBO. For results about CBOs, we used subawarded funds for analyses because they were the most thorough and consistent accounts, and the spending reports to UW from each CBO generally were consistent with subaward line items and did not add any further detailed data. At UW, we had highly granular access to the university's spending data, with a spreadsheet line for every individual expenditure. We coded each line, which yielded the main expenditure categories reported here- of staff, students, indirect costs, and "other." Similarly, the project coordinator at Cornell, Suzanne Gervais, also categorized and reported their institutional spending data, using the same broad categories as UW, for inclusion in this study.

Finally, we consulted internal memos, emails, and field notes related to the Food Dignity project to help us confirm, contextualize, categorize, and explain budgeting and spending decisions as needed during analysis.

\section{Results}

We invested the nearly US\$5 million Food Dignity award in three main categories: about 36\% to CBO support, $40 \%$ to academic support, and the remaining $24 \%$ to supporting and enabling collaboration among and between the organizations. Per capita, individual $\mathrm{CBO}$ s received much less of this pie, receiving $7.2 \%$ of the total amount each, while the universities received $18 \%$ to $22 \%$ each. Therefore, despite the fact that total allocations to academic support versus CBO support were similar (within $4 \%$ ), numerous CBO partners reflected that the budget allocation did not feel equitable in part because the per-organization amounts were so much higher for academic organizations than CBOs (see Figure 1).

Allocations to the five CBO s were very similar, as were expenditures by each university. In all three 
Journal of Agriculture, Food Systems, and Community D evelopment

ISSN: 2152-0801 online

https:/ / www.foodsystemsjournal.org

Figure 1: Food Dignity Spending of the US $\$ 4,978,700$ Budget, by Category, 2011- 2018

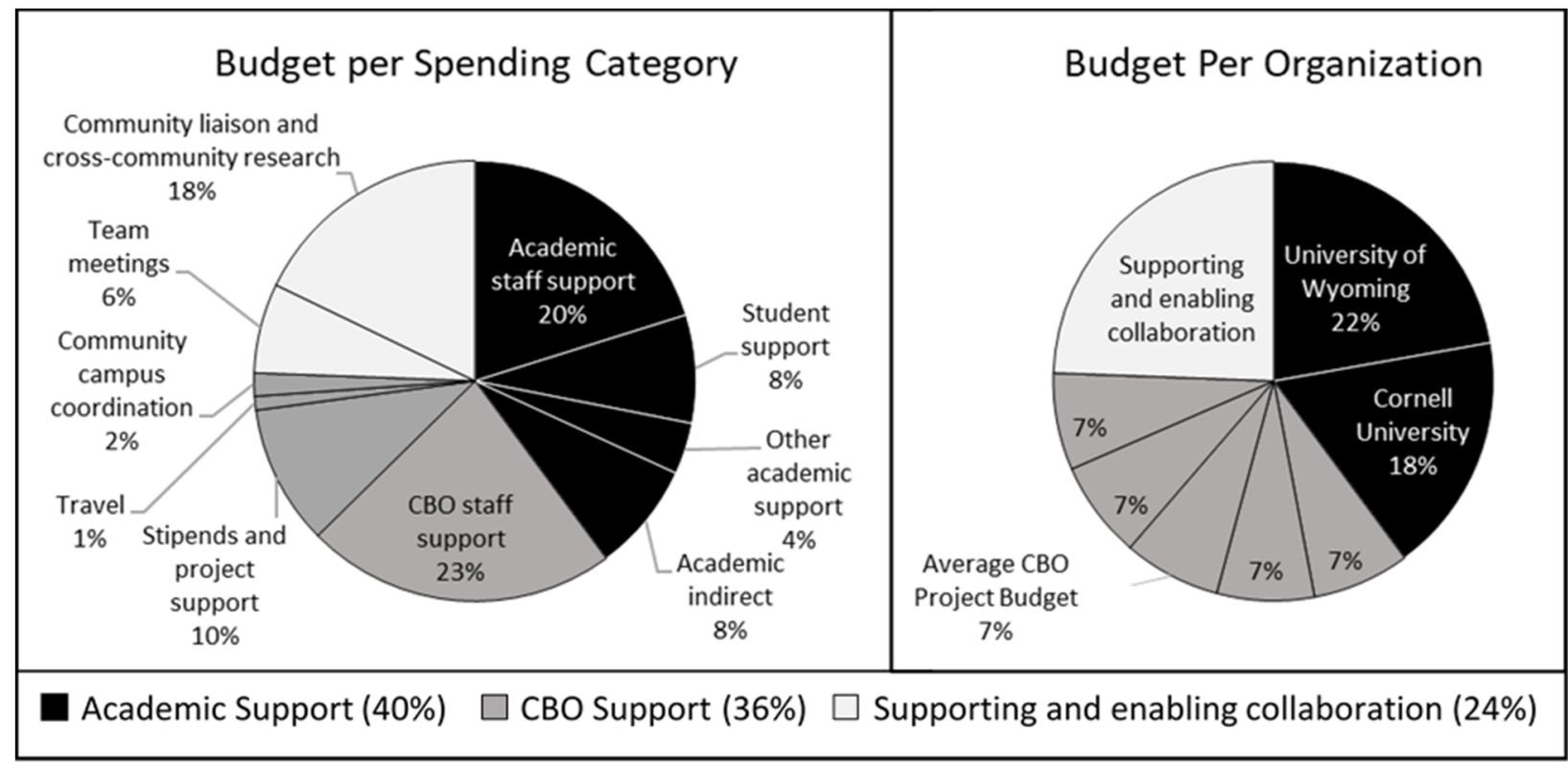

main categories, staffing costs occupy the largest slices- about half for the universities and nearly two-thirds for the CBO s and for the collaboration category (via salary support for community liaison and cross-community research positions).

UW was the awardee and fiscal agent for the USD A NIFA funds. Each organizational partner then received subaward contracts from UW with associated budgets and scopes of work, which were all developed and agreed upon during the proposal development stage. Each sub-awardee organization had the authority to internally reallocate their funds as needed to most effectively meet that scope of work within federal allowable costs rules.

The sections below characterize the allocations awarded to the five CBO partners, the spending by the university partners, and the investments in collaboration among project partners.

\section{CB0 Budgets: U S\$1.78 Million Total}

Each CBO managed a budget of about US\$67,800 per year, on average, during the five-year Food Dignity project (Table 1). From the proposal stage onward, Porter called this the community organizing support pack age. These packages represented the bulk of our investments in the "extension" components of the project, which constituted supporting CBO action. Unusually, the RFA included "implementation of community organizing" as an extension activity (USD A NIFA, 2010, p. 13). The CBO budgets also included lines for research support and a small amount for administration.

Porter proposed draft scopes and budgets to each CBO when preparing the proposal in 2010. Input from each led to some shifts in the plans and allocations ultimately submitted to USD A. For example, BMA wanted to redirect some of the support to founding a tribal farmers market; therefore, their "animator" line was specified for market management instead. ENYF suggested adding Photovoice to the overall research methods. The other CBO s agreed to this, and research materials and the community researcher lines were increased in the first and last years in each CBO budget to help account for that addition.

However, since the community organizing support package was flexible and would be shared as a subaward in the control of each CBO, the organizations mainly embraced the draft plan Porter floated with each, knowing that they could adjust it later as needed. Table 1 provides a summary of the average annual budget for each CBO's community organizing support package.

A core research goal in Food Dignity was to analyze the CBO s' use and assessment of this package as indicators of two things: $\mathrm{O}$ ne, their 
Table 1. Average Annual Community Organizing Support Package Budget for 2011 to 2016, Subawarded to Five Community Organizations a (all amounts in US\$)

\begin{tabular}{|c|c|c|}
\hline Budget category & $\begin{array}{l}\text { Average per CBO } \\
\text { per year }\end{array}$ & Scope and purpose \\
\hline $\begin{array}{l}\text { Community organizer } \\
\text { (salary and fringe) }\end{array}$ & $\$ 26,600$ & $\begin{array}{l}\text { For } 50 \% \text { of a full-time organizer to lead and manage the community } \\
\text { organizing support package work and Food Dignity reporting and } \\
\text { collaboration. }\end{array}$ \\
\hline $\begin{array}{l}\text { Community researchers } \\
\text { (as salary and fringe or stipend) }\end{array}$ & $\$ 12,900$ & $\begin{array}{l}\text { For salary or stipends to compensate people working to answer } \\
\text { community-driven research questions related to Food Dignity }\end{array}$ \\
\hline $\begin{array}{l}\text { Grant manager } \\
\text { (salary and fringe) }\end{array}$ & $\$ 5,800$ & $\begin{array}{l}\text { When the proposed } 10 \% \text { for indirect costs was rejected by USDA, } \\
\text { most CBOs chose to move that funding to this line as a direct cost. }\end{array}$ \\
\hline Minigrants & $\$ 6,000$ & $\begin{array}{l}\text { CBOs designed and implemented how to award these, and to whom, } \\
\text { to support citizen-led work to improve food security or sustainability } \\
\text { in their communities. }\end{array}$ \\
\hline $\begin{array}{l}\text { Community animators } \\
\text { (stipend) }\end{array}$ & $\$ 2,800$ & $\begin{array}{l}\text { For stipends to community leaders to assist with soliciting, } \\
\text { supporting, and tracking minigrant-funded projects. }\end{array}$ \\
\hline $\begin{array}{l}\text { Steering committee } \\
\text { (stipend) }\end{array}$ & $\$ 3,000$ & $\begin{array}{l}\text { Stipend and travel for community leaders, as convened by } \\
\text { community organizer, to support and guide CBO work and to help } \\
\text { design and implement the minigrant program. }\end{array}$ \\
\hline Materials and supplies & $\$ 3,500$ & $\begin{array}{l}\text { For example, cameras for digital storytelling, laptops, refreshments } \\
\text { for meetings, stationery. }\end{array}$ \\
\hline Travel & $\$ 2,000$ & $\begin{array}{l}\text { Any travel related to the project, including for dissemination or } \\
\text { capacity development (travel to annual project meetings was } \\
\text { covered separately by UW's budget). }\end{array}$ \\
\hline Leadership development funds & $\$ 5,200$ & $\begin{array}{l}\text { Piloted as a } \$ 5,000 \text { addition to the package in } 2012 \text { and then } \\
\text { committed for } 2013-2015 \text { at } \$ 7,000 \text { per year per CBO. }\end{array}$ \\
\hline $\begin{array}{l}\text { Subtotal } \\
\text { (not including community/ campus } \\
\text { coordination activities) }\end{array}$ & $\$ 67,800$ & $\begin{array}{l}\text { This is the average annual amount (excluding the two categories } \\
\text { below) that each CBO partner managed, primarily via a subaward } \\
\text { from UW, for Food Dignity work. }\end{array}$ \\
\hline $\begin{array}{l}\text { * Student internship programs } \\
\text { (FLV and WCP only) }\end{array}$ & $\$ 5,000$ & $\begin{array}{l}\text { FLV is geographically close to UW, and WCP is close to Cornell and } \\
\text { Ithaca College. Their scopes of work and budgets also included }\end{array}$ \\
\hline $\begin{array}{l}\text { * Community/ campus coordinator } \\
\text { (FLV and WCP only) }\end{array}$ & $\$ 3,400$ & $\begin{array}{l}\text { funding for supervising and/ or paying student interns and for a } \\
\text { small amount of time for a coordinator to participate in the } \\
\text { development of university minors in sustainable food systems and to } \\
\text { recruit, place, and support interns. Only FLV and WCP received these } \\
\text { additional average amounts each year. Therefore, these numbers } \\
\text { are averaged across only two organizations. }\end{array}$ \\
\hline TOTAL & $\$ 71,200$ & $\begin{array}{l}\text { This is the average annual amount that each CBO partner managed, } \\
\text { primarily via a subaward from UW for Food Dignity work with } \\
\text { community-campus coordination.activities averaged across all five } \\
\text { organizations. }\end{array}$ \\
\hline
\end{tabular}

a The five community-based organizations (CBOs) are Blue Mountain Association (BMA), Dig Deep Farm (DDF), East New York Farms! (ENYF), Feeding Laramie Valley (FLV), and Whole Community Project (WCP).

* Line items marked with an asterisk indicate community-campus coordination activities only awarded to CBOs working directly with participating universities, including Feeding Laramie Valley (University of Wyoming) and Whole Community Project (Cornell University). These budget items are not included in the annual average of US $\$ 67,900$ but are included in the US $\$ 1.78$ million total CBO budget amount.

investments likely signal new strategies that food justice leaders within each CBO wished to try, based on their expertise, priorities, and experience; and two, their spending (combined) and their assessment of the package likely provide insights into how funders and partner organizations can best support the work of such CBO s. Thus, we conducted a separate, more detailed analysis of lessons from CBO budget and spending results 
(see, e.g., Woodsum, 2018b). ${ }^{3}$ However, for the purposes of the research questions in this paper regarding our allocations within the larger actionresearch partnership, we report four findings here.

First, indirect costs, including support covering costs of facilities, are notably absent from this package. Though Porter had proposed a $10 \%$ indirect cost rate on the direct cost budgets for each of the five CBOs and for C-PREP, the supervising accountant at USD A chose not to allow the indirect costs for those organizations. In consultation with each organization, UW converted those funds to direct costs instead, in most cases as salary for staff who managed the subaward administration. The loss of the flexibility of unrestricted indirect funds was a blow for the CBO s. The inequity of it was magnified by the substantial indirect cost amounts awarded to the universities. The lack of unrestricted indirect costs created particular hardship for the smallest organizations. O ne leader illustrated this vividly by wondering if they were supposed to "work out of the trunk" of a personal car.

Second, although CBO s were allowed to move funding between lines in their subawards, their spending reports to UW tended to mirror or even replicate the budget allocations as originally laid out in the grant application. Though each CBO did spend its money in ways designed to maximize impact on its desired outcomes while meeting the Food D ignity scopes of work, many of the organizational leaders reported feeling constrained by the proposed allocations, feelings based on decades of experience with nonflexible funding and also because of the power UW held over this funding.

Third, most of the CBO s could not afford to front the costs of implementation for later reimbursement, which is the funding structure generally used by federal funding agencies. This meant that UW needed to modify typical funding procedures to provide advance payments for CBOs.

Fourth, both need and opportunity for food justice action and knowledge generation outstripped what this package supported, which we made

3 For example, a consensus among the $\mathrm{CBO}$ s was that this package had too many small pots of money, especially for stipends (including "animators," minigrantees, steering up for in only small part via transfers from university budgets to $\mathrm{CBO}$ ones over the course of the project. These last two budgeting issues and results are described in more detail below.

A dvance payments to $\mathrm{CBO}$ s

Like most funders, federal funding agencies pay grantees in arrears for project-related costs. However, this reimbursement system only works for organizations that have enough credit and cash on hand to pay these costs and to safely carry them for at least six months before being paid back. As a doctoral candidate when putting together the Food Dignity proposal, Porter was ignorant of normal practice when applying for the funding and presumed that UW would pay subaward amounts to CBOs in advance.

When the proposal was awarded, the UW Research O ffice did, in fact, agree to do that. For the $\mathrm{CBO}$ s that requested them, UW provided quarterly advances and then later, to reduce paperwork burdens and increase CBO flexibility in spending decisions, six-month advances. This was essentially a loan from UW to each CBO, which the USD A then "repaid" about nine months later when UW expenditures were approved and reimbursed.

Reallocations to C B0 s from U niversities In the original 2010 project proposal, the average CBO's total budget allocation was US\$314,800, or about US\$63,000 a year. In practice, by the end of the project in 2016, the actual average allocation to each CBO was US\$356,200, or around US\$71,200 per year (including the community-campus coordination funds awarded to FLV and WCP only, as shown in Table 1).

This increase to CBO budgets decreased university budgets by US $\$ 207,200$ over five years. This represented about $10 \%$ of UW and Comell's direct cost funding out of the original allocations and added US\$8,200 a year to the average annual budget for each CBO.

WCP and FLV each received more of these

committee members, and research assistants), without proportionate and sufficient amounts to pay CBO staff for recruiting, supporting, managing, and mentoring them. 
reallocations than the other three $\mathrm{CBO}$ s. This was, in rough proportion, the additional research and, especially, education-related requests that Cornell and UW made of each because of their geographic proximity. In Laramie, we decided to move nearly all the US $\$ 40,000$ in student internship money that was originally in the UW budget to FLV and the remainder to BMA. In Ithaca, Cornell drew from part of the graduate student budget savings (see below) to increase the salary of the WCP community organizer. Cornell contributed the rest of these savings to adding a leadership-development component to the CBO packages.

During the first three years, Porter asked community-based researchers two or three times each year if they would like to travel to co-present joint work at national conferences, ultimately paying US\$12,2004 in community partner travel expenses. She agreed with CBO leaders that allocating money directly to their budgets would be better, practically and ethically, instead of Porter making these travel invitation decisions. In addition, by the third year of the collaboration, the CBO s had explicitly identified leadership development as one of their most important, but most underfunded, activities. Thus, after piloting a US\$5,000-per-CBO version of leadershipdevelopment support in the second year, mostly from Cornell contributions, UW committed US\$7,000 per organization per year for the final three years of Food Dignity for leadershipdevelopment work. This additional US\$26,000 per CBO was tied to a leadership-development plan for action and for briefly sharing outcomes and learning from that action. In other words, this reallocation to CBO s added at least as much workload as it did money to pay for it.

U niversity Budgets: U S\$1.99 M illion T otal Over seven years (including the two no-cost extension years), UW spent US\$1,108,000 and Cornell spent US\$882,900. Central administration of each university took a total of about $20 \%$ of these amounts as indirect costs, leaving academic

4 This amount is included in the "collaboration" spending results because convening at such events for our presentations also functioned as informal team meetings, and because it was partners with US\$1,590,900 to spend directly on Food Dignity work.

At the start of the project, Porter had mischaracterized these community vs. university allocations in two key ways. O ne, she excluded indirect costs in her framing calculations regarding how equitable (or inequitable) the Food Dignity allocations were. However, the approximately US $\$ 500,000$ for facilities and administration obviously supplied substantial institutional support to the two universities, while the $\mathrm{CBO}$ s received none. Two, though she had explicitly called the CBO allocations the community organizing support pack age, Porter initially did not think to name the university financial support as a package as well. Failing to name and publicly quantify the university packages served to naturalize and normalize the substantial allocations to academic institutions, making them nearly invisible in our public discussions about Food Dignity. She realized this while preparing slides about the project budgets for a CCPH presentation about Food Dignity in 2014. From then on, she called the university funding the university support pack age.

The following sections characterize the directcost allocations and spending in the university support packages. Figure 2 summarizes overall spending at the two universities.

A cademic staff As with the $\mathrm{CBO}$ s, the universities' largest expenditure category was staff salaries plus fringe (which cost an additional $50-60 \%$ of salary to pay, for example, for health insurance and retirement contributions). At UW, this staffing was almost entirely for project coordination and research assistance. Starting in 2013, this role was filled by a full-time research scientist, Alyssa Wechsler. At Cornell, this staff budget supported fractions (10-25\%) of the time for senior project coordinator Suzanne Gervais, agroecology lab technician Heather Scott, and for people who coordinated the development of a new community food system undergraduate minor. This also paid for $15-40 \%$ of Monica

not spent in university support nor was it under direct CBO control. 
Figure 2. Spending of the Food Dignity Grant by Category by the University of Wyoming and Cornell University, 2011-2018

Although the University of Wyoming's overall spending was higher than Cornell University's (US $\$ 1,108,000$ versus US $\$ 882,900$ ), they had similar proportional spending by category, so their spending is combined here (total budget of US\$1,990,900).

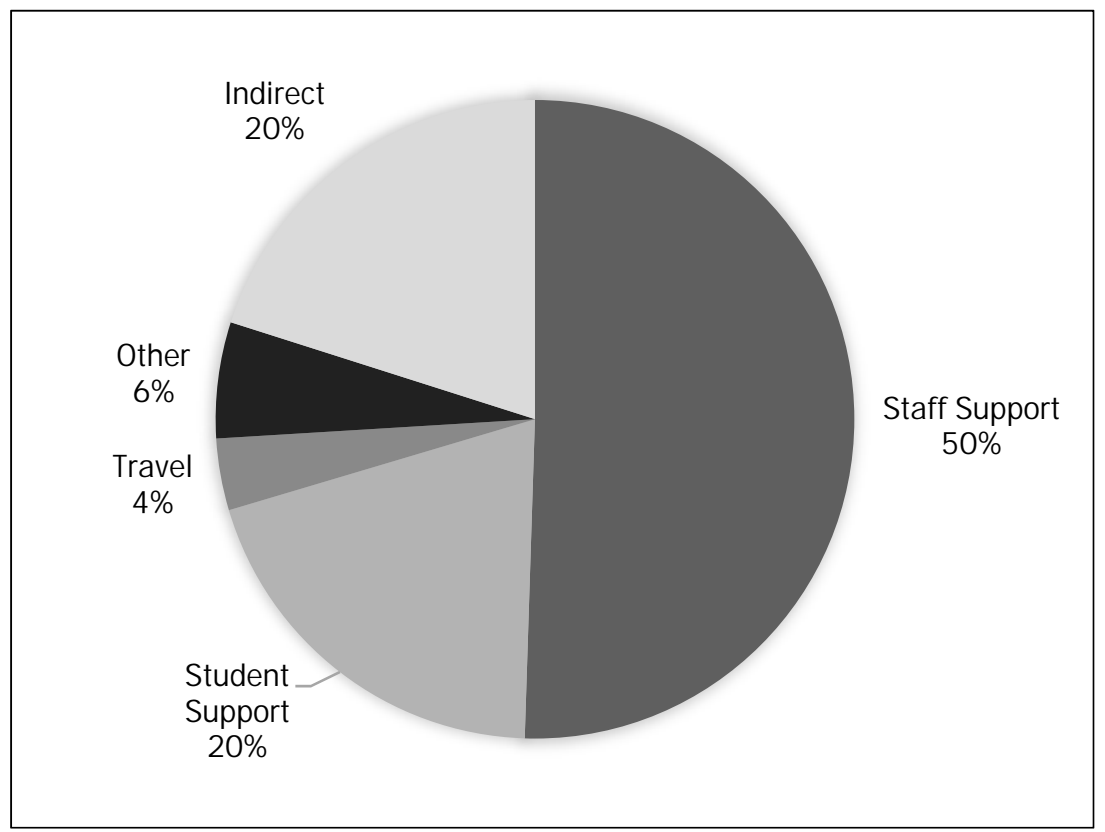

third of a full-time, 12-month salary during summer months if she garners funding for it. Porter originally budgeted to pay $80 \%$ of her three-month summer salary and fringe with Food Dignity funds in each of the five planned project years. In practice, she paid herself for $39 \%$ of her time, on average, across the seven years, for her nearly fulltime work in the summer months. Savings went toward increased allocations to CBO partners. That said, these savings were limited both by Porter receiving raises on her ninemonth salary (which was US\$54,600 for 2011-2014 and went up to US\$74,500 in 2015) and by extending the project by two years. Also, of course, Porter could have elected to use all of these funds differently instead of paying herself.

Hargraves' time for her leadership on minigrantrelated research. Hargraves' scope later expanded to encompass WCP research support; conceiving and co-developing collaborative pathway models with each CBO (Hargraves \& D enning, 2018, this issue); and becoming part of the overall project leadership team with Porter and $\mathrm{G}$ ayle Woodsum. A much smaller portion of the staff spending includes paying for some short-term, part-time, hourly work on Food Dignity research conducted by people who had previously been graduate students with the project.

Porter was the only faculty member on the project for whom Food D ignity paid any salary costs. As is common in universities, UW pays Porter a salary for nine months during the academic year. She is allowed to earn the remaining

\footnotetext{
5 Employees whose salaries are paid from funds provided only for a specified time frame, such the five-year USD A grant for Food Dignity, and whose employment will end unless new money is secured, are said to be on "soft money." Those who
}

Other than this summer pay for the principal investigator, the cost of tenured or tenure-track faculty time spent on Food Dignity work is nearly invisible in our budget analysis, as they were not paid by the project but instead supported by hard money salaries ${ }^{5}$ (plus costs of fringe benefits) as land-grant university employees during the academic year. At Cornell, none of the faculty coinvestigators- including Scott Peters, Phil McMichael, and Laurie D rinkwater - received a salary from this grant. They each committed 5$10 \%$ of their time to its research and education goals as part of their academic jobs (both by advising graduate students and teaching), and any contributions during the summer were uncompensated. At UW, Porter spent at least half her academic-year time on this project during the first five years, including developing and teaching new

are paid from funds expected to be stable, such as tuition money, state support, and indirect costs that UW receives, are said to be on "hard money." 
food system courses. The state of Wyoming, via UW, paid for nearly all ${ }^{6}$ of this time, with a price tag of about US $\$ 197,300$ (including fringe). This amount alone would have been equivalent to $21 \%$ of the total UW direct budget in the Food D ignity grant.

\section{$\mathrm{G}$ raduate students}

The second largest direct spending category at each university was funding graduate students. USD A funding for Food Dignity paid in full for the studies of five masters students with Porter at UW (Peggy McCrackin, Shannon Conk, Elisabeth "Livy" Lewis, Melvin Arthur, and Lacey Gaechter). The cost of each degree, over a two-year course of study, was about US\$43,000 (US\$216,000 total for the five students). At Cornell, annual graduate student support packages cost more than double UW's, with higher tuition and, at that time, approximately US $\$ 22,000$ in academic-year stipends (vs. the US\$11,400 UW graduate students received in an academic year; additional summer funding was paid to students in some years at both institutions). The project supported about twothirds of the costs for one doctoral student, John Armstrong, who worked with Peters. Armstrong spared Cornell's Food Dignity budget about US $\$ 80,000$ by garnering other assistantships to pay the other third, intentionally freeing up some funds for transfer to CBO partners. The Cornell budget was also used to support small portions of the studies of two agroecology students who studied with D rinkwater. The total Food Dignity support for Ph.D . students at Cornell was about US\$180,100.

Roughly half of graduate students' time went toward Food Dignity-related teaching and research. In this sense, some of the graduate student support could be considered a staffing cost.

T ravel and other

The rest of university spending was on travel and on expenses categorized as "O ther," such as stipends to community-based research collaborators

6 The Food Dignity grant did also pay UW back for a small portion of Porter's academic-year work; a US\$25,300 "buyout" of her time went toward paying adjunct instructors to and participants who were not receiving salaries from the CBOs as co-investigators (US\$25,000); interview transcriptions and general materials and supplies (US\$25,900); expenses (not including travel) related to information dissemination such as publication and printing (US\$20,100); expenses related to the Team GROW project at UW (US\$9,000); and honorariums to Food Dignity partners for contributions to final project outputs in the final years of no-cost extension (US\$37,000).

Travel budgets funded conference presentation expenses and visits to CBO partners. For example, at UW, conference travel cost US\$16,900 over the course the project, paying in part or in full for Porter's travel related to 32 Food Dignity presentations and posters. Her travel to visit with project partners cost an additional US\$11,500, funding 15 trips in total to WCP, ENYF, and D DF, plus 16 to BMA in Wind River Indian Reservation. (Porter is co-located with FLV, so visits with that organization did not incur travel costs.)

Supporting and E nabling C ollaboration:

U S\$1.22 M illion Total

We invested US\$1,218,400 in our team's collaboration work primarily in two ways. Nearly threequarters of the nearly US\$1.22 million went to support cross-community research and community-liaison services, including salary and travel for a liaison between community and academic partners. D uties for the community liaison role included advocating for $\mathrm{CBO}$ interests in the project; co-investigating research on the collaboration itself; and assisting $\mathrm{CBO}$ s with their research contributions. We began the project with Hank Herrera at C-PREP in the designated role of community liaison; he also was a manager at $\mathrm{CBO}$ partner D DF. About halfway through the project, most of that scope of work and associated funding was transferred to Action Resources International (ARI), led by Gayle Woodsum. ARI also houses the CBO partner FLV.

The rest of this collaboration budgetUS $\$ 328,700$ over the five years- paid for our eight

teach two courses a year, in lieu of Porter. This amount is excluded from the state-funded contribution listed. 
national team workshop meetings. This covered food, lodging, and transportation for the participating team members. The size of meetings ranged from 8 to 38 people, with an average of 28 and a median of 33 participants. This also includes retaining facilitation and training services of Lila Cabbil twice and also of Malik Yakini, Eric HoltGiménez, and StoryCenter. For example, 18 of us met in Oakland for four days in January 2015, including three days with StoryCenter, to produce digital stories of our individual journeys fighting for food justice and Food Dignity, contribute to a minidocumentary about that process, and produce brief stories about others in our organizations or lives who have inspired us. That meeting cost about US\$58,100, including postproduction work by StoryCenter. These team meeting figures do not include the substantial staffing costs of organizing the meetings, provided mostly by the project coordinator at UW (Wechsler), but also by the community-campus liaison and, to a lesser extent, the leader at each partner organization.

Funding for team meetings was held within the UW budget, meaning that Porter ultimately controlled these dollars and that the institution received indirect costs on this sum.

\section{Discussion}

The results above outline our funding allocations and spending among the community and academic partners in the Food Dignity project. Of the nearly US\$5 million budget, 36\% went to five CBO s, 40\% to two universities, and the remaining $24 \%$ was invested in supporting and enabling our collaboration.

We believe this is the first paper to share and assess such complete data on action-research project allocations and spending. On their own, these figures provide some transparency in that they highlight the use of these public monies and provide some technical benchmarking for others who are budgeting for such large, multigoal, multistakeholder projects. In this discussion, we consider these decision-making power, allocation, and spending results as an empirical indicator of equity and power-sharing, or lack thereof, in our community-university partnership. As outlined below, we find that our allocations reflect and reproduce systematically unbalanced power relations between academic and community partners. We call this systemic imbalance academic supremacy.

(In)equity and 0 ur (Re)Production of A cademic Supremacy O ur inequity problems begin with the overarching issue of one academic person- Porter, in this case- having the singular and sole power to allocate the Food Dignity budget (within both the confines of the scope agreed upon by USD A and collaborators and within funder and UW spending rules). By granting subawards to each $\mathrm{CBO}$, she elected to devolve some of this power to the directors of each organization who, in turn, had authority over their budgets and spending. However, as indicated in the paper by Cain et al. (2014) about NIH-funded CBPR projects, only half of the academic grantees in their review issued funding to their community-based partners directly. This hierarchy of power institutionalizes inequity. Our inequity problem in Food Dignity, similarly, stems from who allocated the funding (i.e., Porter) and how she allocated it.

If the benchmark for assessing equity in our Food Dignity allocations were comparable with the limited data highlighting how other CBPR projects have spent their money, our allocations come out well. For example, if we used the approach of Cain et al. (2014) for categorizing spending in NIHfunded CBPR projects, both the CBO allocations and nearly all of the investment in our joint collaboration would have been counted as "community." By this count, Food Dignity's community vs. academic spending would be roughly $55 \%$ vs. $45 \%$, respectively, as opposed to the $30 \%$ vs. $68 \%$ averages identified in that review.

However, the benchmark for equity is not what is, but what should be. By this measure, Food D ignity allocations and spending fare less well.

In our analysis of these (in)equities, we suggest the phrase academic supremacy to signal the systemically inequitable social relations between university partners (individually and institutionally) and community-based people and organizations, that 
are pervasive and institutionalized in U.S. society. ${ }^{7}$ A scholar discussing nonprofit funding more generally describes this problem as "institutionalization of a relation of dominance" (Rodríguez, 2007, p. 39).

Because academia is not integrated across U.S. society to the extent to which, for example, race and gender are, this form of oppressive relations is not as ubiquitously experienced as, for example, racism and sexism. Also, as with all forms of social oppression, it is intertwined with, or "intersectional" with, these other forms of oppression. For example, in Food Dignity, many of the community partners are people of color, while nearly all the academic partners are white, including Porter (see Gaechter \& Porter, 2018, this issue). Because the project was a community-university collaboration, concrete manifestations of academic supremacy impacted our everyday work and structural relations. These manifestations included producing and reproducing inequities in our monetary resource allocations in at least four main arenas: employment conditions, institutional support, capacity development, and autonomy and control of the funding.

\section{E mployment conditions}

Employment conditions within academic institutions are generally more favorable than those in CBO s in terms of salary, and even more so in terms of benefits (in particular, employer contributions to retirement funds and health insurance premiums) and job security. On average, this was certainly the case in Food Dignity. To some extent, this was determined by Porter's budgeting. This, in turn, was shaped by pay scales and policies within each partner organization.

These differences are systemic. For example, UW and Cornell required that grant funds pay fringe rates equivalent to $41 \%$ and $56 \%$, respectively, on top of any salaries paid out of the award (with indirect costs charged on top of that). Of the

\footnotetext{
7 The systemic, institutionalized nature of this power imbalance, which we call academic supremacy, confers privilege to individual academic partners over community-based researchers. However, it does not mean that we claim individual academics are academic supremacists. Similarly,
}

five $\mathrm{CBO}$ s, only ENY F submitted a budget with fringe on top of salaries, at a $32 \%$ rate. (In addition, the parent organizations housing D DF and WCP explicitly told Porter that their fringe costs would be covered by other sources.) D irectly related to fringe rates on pay, all academic partners enjoyed health insurance benefits, whereas only some CBO-based partners could afford to offer those benefits.

Also, except for one director-level civil servant working with DDF, none of the community-based collaborators enjoy any job security. In universities, for tenure-track academics- as stressful as the six years of tenure-clock ticking are designed to bethe tenure process entails nearly certain job security for seven years with the additional promise of lifelong job security if tenure is awarded. Even for the university-based collaborators paid by soft money from grant-funded work, including Food Dignity funds, salaries and benefits were relatively secure; everyone who was employed by the university partners before the project started remained employed when the project ended. By contrast, nearly everyone working with the CBO partners was paid out of soft money, which sometimes made simply making payroll challenging for some of the organizations. Jobs were frequently at imminent risk. Funding program continuity or growth was a challenge for all five CBOs. Overall, most of the individual collaborators based in academic organizations enjoyed better benefit packages, more job security, and better salaries than most of the community-based partners. The universities that employed them never had to worry about whether they could meet payroll and continue their teaching, research, and service work.

However, there was one group within the academic setting that did not receive better pay rates: graduate students, who received between US $\$ 11,400$ and US $\$ 27,400$ a year in assistantship stipends (with the top end of that range including stipend increases over the five years and summer

systemic racism in U.S. society yields white supremacy, which in turn generates white privilege for white people in the U.S. (even if many simultaneously endure other individual or systemic forms of suffering); however, very few white people are white supremacists. 
pay at Cornell). The idea in Minkler et al. (2003) that community-based co-investigators be paid at student rates is remarkable, and not in a good way, as illustrated by two other essays in this issue- one by the FLV founder and Food D ignity communityuniversity liaison (Woodsum, 2018b) and the other by graduate students in Food Dignity (Bradley, G regory, Armstrong, Arthur, \& Porter, 2018). Experienced community leaders and organizers often mentor graduate student researchers, as they did extensively in Food D ignity. For example, after a joint presentation about our work in late 2015 by Sequeira and Porter, an audience member asked Sequeira afterward if she had been Porter's Ph.D . committee chair. In addition, all students received tuition, health insurance, and ultimately degrees along with their stipends. Therefore, student pay rates would provide a highly disrespectful benchmark for community-based researcher pay rates. Other systemic inequity issues with capacity development investments are discussed below.

Especially in a project specifically about documenting and sharing the expertise of communitybased partners, we should have met the CNREI standard of paying the same rates for academic and community-based time and expertise. However, we failed to meet these standards. In some of the $\mathrm{CBO}$ s, with flexible pay rates determined in-house, providing higher pay would have been an option. When that was not possible, then paying higher fringe rates to cover benefits and covering a greater portion of salaries would have helped to ameliorate, though not eliminate, these inequities.

\section{Institutional support}

Like all public academic institutions, UW and Cornell enjoy systemic financial support in two forms that CBOs do not: substantial indirect cost income and public investment.

Universities receive significant indirect cost income from external grant funding. For example, universities received US\$399,900 of indirect cost income during Food Dignity while CBO s received none. Even when funders do grant $\mathrm{CBO}$ s some indirect costs, the amounts are much smaller than the actual overhead. They also exclude a category of direct costs that are actually among the most resource-intensive for many $\mathrm{CBO}$ s to administer: "participant support costs." These are "direct costs for items such as stipends or subsistence allowances, travel allowances, and registration fees paid to or on behalf of participants or trainees (but not employees) in connection with conferences, or training projects" (Uniform Administrative Requirements, 2014, p. 90). We do not know why federal funders exclude these from indirect cost payment calculations; tuition costs for graduate students are also excluded, and perhaps the idea is that this kind of capacity development involves minimal administration and is part of the academic mission. For example, for universities, this category includes paying cash stipends to research participants and honorariums or per diem expenses to external advisers. However, for $\mathrm{CBO}$ s that extensively support "participants" as mentees and developing leaders with this funding line, excluding them compounds the hardship of having low or no indirect cost funding to cover basics such as bookkeeping and accounting. Public universities also receive general-purpose support from state governments. For example, UW receives about a quarter of a billion dollars each year in general state funding (UW O ffice of Academic Affairs and Budget Office, 2013). In contrast, the two Wyoming-based CBOs in Food Dignity - FLV and BMA - receive US\$0 in such general funds. Though public funds for higher education have been decreasing, sometimes dramatically, over the last decade (Mitchell, Leachman, \& Masterson, 2016), the funding provided is still substantial.

Overall, one of our major failures in Food Dignity was insufficient attention to supporting the five CBO s in building financial sustainability, particularly in the face of these systemic inequities. This should have included, for example, allocating much more funding for direct overhead costs, staff time, and capacity development for each organization.

Moreover, as the ones with the experiential expertise and practical wisdom about how to build equitable and sustainable community food systems, the $\mathrm{CBO}$ s led or co-led much of our research, and community-based partners served as co-investigators in all that work. In addition, leaders from FLV and WCP were heavily involved in formal education as guest instructors, internship coordinators, 
and co-planners of new sustainable food system minors at UW and Cornell. Most of the graduate students involved with Food Dignity worked under CBO supervision and mentorship at some point. And yet universities are the organizations with core funding - before, during, and after any grantfunded project- for paying tenure-track academics to generate and document new knowledge and to provide formal education and student mentorship.

\section{Capacity development}

Food D ignity replicated trends of making much heavier investments in capacity development for academic-based partners, mainly in the form of graduate students, than in community-based partners.

Funding streams for research, in general, tend to value producing graduate students, without any comparable support for capacity development among community-based partners. In Food Dignity, we spent US\$396,000 to fully fund five people earning master's degrees and partially fund (in some cases paying only a small fraction of the costs) three doctoral students who earned Ph.D.s. Such degrees count as an output on their own for our funder. Also, these substantial investments benefited not only our project (via staffing our action research and increasing our number of peerreviewed publications) but also the graduates themselves. On average, those with a master's degree earn about 20\% more and are less likely to be unemployed than those with a bachelor's degrees; personal income gains are as much again for those with a Ph.D. over those with a master's degree (Bureau of Labor Statistics, 2017).

In addition, while well beyond the control of this project, the convention of faculty being able to take a paid sabbatical every seven years is another way in which this inequity manifests itself. (For example, Porter was on paid sabbatical when she wrote the bulk of her contributions to the manuscripts in this issue.)

Capacity development investments for CBO partners in Food Dignity comprised mainly minor travel funding for conference and workshop participation, totaling about US\$10,200 per CBO, or US $\$ 50,800$ for the overall project. The UW budget was also used to cover US\$13,100 in community partner travel directly. This was later supplemented with the addition of leadership development funds totaling US\$26,000 per CBO , or US\$130,000 total for all five CBO s over five years.

However, even with this addition, the total CBO capacity investments, across dozens of people in five organizations, are only $49 \%$ of what Food Dignity spent on supporting eight graduate students. This is compounded by the risks of our university food system degree programs professionalizing, and therefore also likely weakening, food justice work (Boyte 2004). What if one of our graduates were hired over a grassroots community leader because they now have formal food system qualifications (Holt 2015)? As with the other three forms of academic supremacy discussed here, this differential perpetuates and widens inequities between academic and community partners.

4. A utonomy and control with funding Federal research funders strongly favor large, and largely academic, organizations as primary grant holders via extensive grant administration requirements, payments made as reimbursements, and insufficient de minimus indirect cost rates. This means that a university is nearly always the primary grant-holder in community-university partnerships- as was the case with Food Dignity, the projects with papers about their budgeting reviewed above, and in 48 of the $49 \mathrm{NIH}$-funded projects reviewed by Cain et al. (2014). Particularly in the absence of funder guidelines regarding budget allocations, this means that academic organizations control resource allocation, including which organizations and partners are invited to participate and how much funding each receives. Individual and organizational partners can choose to negotiate, but most decision-making power resides in the hands of the awarded organization, which is almost always an academic one.

In addition, the high negotiated indirect cost rates universities receive provides them with extensive unrestricted funds that $\mathrm{CBO}$ s do not receive. For those who receive them, these funds not only support management of current grants but are often invested in securing future ones, such as via research "start-up" funding for new faculty members, internal pilot project grants, and grant-writing 
support.

Providing subaward funding, controlled by each organizational partner in Food Dignity, slightly ameliorated, but far from resolved, these inequities. Flipping that common funding model, so that $\mathrm{CBO}$ s receive the funds and subaward them to academics, would be one step toward ending those inequities.

\section{L imitations, 0 verlaps, and M argins of $E$ rror}

For the purposes of this paper, the accuracy of our data does not present a limitation of our work. We believe the spending numbers reported here are accurate to at least the nearest thousand dollars. Some of this spending we could calculate to the dollar, although we rounded to the nearest hundred in this paper for ease of reading (and, in a few cases, this rounding means not all numbers add up precisely).

How we allocated dollars to each of the three main categories (CBO s, universities, and collaboration) was a little rougher, especially in two cases. One case is that Katherine "Katie" Bradley was a paid team member from the start of the project, at first as an employee of C-PREP. At that time, she was also finishing a master's degree, without Food Dignity support, and starting a Ph.D. program at the University of California, D avis (UC D avis) and already collaborating with DDF. When we ended the project's relationship with C-PREP, Porter retained Bradley first as a Ph.D . candidate and then as a post-doctoral scholar via a three-year, US $\$ 94,400$ subaward to UC D avis. Her role of working closely with DDF in particular did not change. For simplicity, and because UC D avis was not a collaborator in the Food Dignity project beyond Bradley individually, we counted these numbers as cross-community research and included them in the "collaboration" totals. The other case is that UW paid salary and benefits totaling US\$43,100 to an employee and former Food Dignity master's student, Peggy McCrackin, who in practice worked directly for FLV during that time. This amount is included in the UW university budget section above. Net, this means we may have overstated the collaboration budget and understated the university budget by just over US\$51,000. Y et some other expenses appearing in the university budgets were spent on collaboration with one or more of the $\mathrm{CBO}$ s, such as food for community-university meetings, stipends to nonsalaried community research partners, and honorariums for higher education work by community leaders. In addition to those two cases, it is worth noting that Ithaca College was also a partner organization in Food D ignity but had a very small (US\$2,000 annually) education-related budget managed via the WCP subaward and a travel budget for dissemination administered by UW.

In the end, any overlaps or allocation questions about these dollar amounts, within or between categories, are small enough that they do not affect any of the implications or conclusions that can be derived from these results.

F uture Research

O ur real limitations lie in what implications and conclusions can be derived from these results. For example, because this is the first paper we know of to analyze project spending in a communityuniversity action research collaboration, we have little context for making comparisons and contrasts. Also, because systemic forms of power and privilege are embedded and naturalized (such as failing to name and quantify university support packages the way we named and quantified community packages), we have likely missed many ways that academic supremacy manifested itself in our allocations and spending during the Food Dignity project. What we do see has largely been shown to us by the community-based partners in the project, especially Woodsum, who has reviewed and commented on this manuscript and provided original analysis in related essays in this issue (2018a, 2018b).

Having comparable spending data available across multiple community-university action research collaborations would enable a more thorough investigation of what grant-spending strategies are most effective for reaching project goals. This would allow an assessment of whether the steps for equity proposed below truly work; it would also allow an assessment of the associations between partnership equity and project effectiveness. Based on our experience in Food D ignity, we hypothesize that this is causal. We also claim that, 
regardless, seeking equity is an ethical imperative.

\section{Conclusions}

The allocation of funding among and between community and university partners in Food Dignity illustrates our project's production and reproduction of systemic inequities in community-university collaboration relations, even as we strived to establish equitable research relations. In Food Dignity, this systemic dominance manifested in better employment conditions, greater institutional support, higher capacity development investments, and more financial autonomy and control for academic partners than for community ones. More generally, we have named these systemic and structural inequities as academic supremacy.

Early systemic steps towards assessing and undoing these inequities could include the following: (1) increasing de minimus indirect cost rates and standardizing negotiated ones; (2) including budget-equity assessments in evaluation of community-campus action research funding proposals and annual funding reviews, thus fostering financial transparency in allocations and spending in federally funded research; and (3) creating sabbatical systems to support CBO leaders in codifying their expertise. In addition, mechanisms for granting awards directly to $\mathrm{CBO}$ s and joint awards to community and academic grantees would increase CBO control. Means for at least partially prepaying for grant expenses are also needed for small organizations. The budget equity evaluations and granting awards to CBO s directly in particular would both help create a driving motivation for universities and individual academics to build equitable research partnerships.

Individual academics forming such collaborative partnerships can help bring these changes into action through internal advocacy in our institutions and with funding agencies and with individual practices in forming community-academic partnerships. These practices include, for example, adhering to the CNREI's guidelines outlined in the introduction for co-designing budgets and maximizing equity in pay rates; minimizing stipend-based work; co-designing and selecting project staffing; investing in financial sustainability and capacity development with community partners; negotiating with our universities to prepay subawards as needed; budgeting for direct administrative costs to help bridge inequitable indirect cost rates; and providing face-to-face meetings and other collaboration, capacity, and relationship development. No individual academic or university can create the systemic changes needed alone. However, these actions help point the way while slightly ameliorating inequities in the meantime.

Consider an analogy with the meme image adapted to illustrate equality vs. equity with three people of varying heights trying to watch a baseball game over a fence (Figure 3 ).

The equality image shows the three people 
standing on boxes of the same size, which means the shortest of them cannot see over the fence. The equity image shows the boxes reallocated so the shortest person reaches the same height as the tallest, so she can see over the fence as well. Some versions of this meme include a third image of reality, with the tallest person on extra boxes and/ or the shortest person standing in a hole. Distributing funding equally in a $\mathrm{CBO}$-university collaboration, in proportion to scopes of work, will leave a partnership closer to this "reality" scenario than to an "equity" one because CBO s are systemically less resourced than are universities.

Undoing the systems of academic supremacy, including the forms outlined here, is a transformational project. No single project action can eliminate these institutional inequalities any more than, for example, feminist efforts of individuals and groups can end patriarchy. However, we must name these inequities and intentionally design our actions to reduce them, or we will end up reproducing them. Perhaps we can find seats in the grandstand for all three of the spectators who are trying to watch the game over the fence, or maybe we could be playing a different game all together.

\section{Acknowledgments}

We are grateful to the action research teams of Food Dignity and the Community Network for Research Equity \& Impact team of CommunityCampus Partnerships for Health. We especially thank Suzanne G ervais of Cornell University for her help with that institution's figures.

\section{References}

Boyte H. C. (2004). E veryday politics: Reconnecting citizens and public life. Philadelphia: University of Pennsylvania Press.

Bradley, K., Gregory, M. M., Armstrong, J. A., Arthur, M. L., \& Porter, C. M. (2018). Graduate students bringing emotional rigor to the heart of community-university relations in Food Dignity. Journal of A griculture, F ood Systems, and Community D evelopment, 8(Suppl. 1), 221-236. https:/ / doi.org/ 10.5304/ jafscd.2018.08A.003

Bureau of Labor Statistics. (2017). E mployment projections: U nemployment rates and earnings by educational attainment, 2017 [Figure]. Retrieved from http:// www.bls.gov/ emp/ ep chart 001.htm

Burhansstipanov, L., Christopher, S., \& Schumacher, S. A. (2005). Lessons learned from community-based participatory research in Indian Country. C anœer Control, 12(Suppl 2), 70-76. https:/ / doi.org/ 10.1177/ 1073274805012004 S10

Cain, K. D., Theurer, J. R., \& Sehgal, A. R. (2014). Sharing of grant funds between academic institutions and community partners in community-based participatory research. Clinical and Translational Science, 7(2), 141-144. https:// doi.org/ $10.1111 /$ cts.12149

Community-Campus Partnerships for Health [CCPH]. (n.d.). G uiding principles of partnerships. Retrieved July 8, 2018, from https:// www.ccphealth.org/ guiding-principles-of-partnerships/

Community Network for Research Equity \& Impact [CNREI]. (2013). C ommunity leaders from across the U.S. call for health research equity \& impact: $H$ ighlights from the 2nd N ational C ommunity Partner F orum, D eeember 5-7, 2012. Retrieved from https:/ / ccph.memberclicks.net/ assets/ D ocuments/ CNREI/ ncpf2-briefreportfinal.pdf

Ethics of dissemination: Communicating with participants about genetics research. (2010). Retrieved from the National Institutes for Health website: https:/ / projectreporter.nih.gov/ project info description.cfm?aid=7765660\&icde=35705412

Foucault, M. (1972/ 1980). Power/ knowledge: Selected interviews \& other writings, 1972-1977 (C. Gordon, L. Marshall, J. Mepham \& K. Soper, Trans.). New York: Pantheon Books.

Foucault, M. (1975/ 1995). D iscipline and punish: the birth of the prison (A. Sheridan, Trans.). New Y ork, NY: Vintage Books.

Froehle, C. (2012). E quality to a conservative and to a liberal (Image). Retrieved from https:/ / plus.google.com/ +CraigFroehle/ posts/AdKcNKesX wa

Gaechter, L. \& Porter, C. M. (2018). "Ultimately about dignity”: Social movement frames used by collaborators in the Food Dignity action-research project. Journal of A griculture, F ood Systems, and C ommunity D evelopment, 8(Suppl. 1), 147166. https:/ / doi.org/ 10.5304/ jafscd.2018.08A.004

Gehlert, S., Fayanju, O. M., Jackson, S., Kenkel, S., McCullough, I. C., O liver, C., \& Sanford, M. (2014). A method for achieving reciprocity of funding in community-based participatory research. Progress in C ommunity $\mathrm{H}$ ealth Partnerships- 
Research E ducation and A ction, 8(4), 561-570. https:/ / doi.org/ 10.1353/ cpr.2014.0054

Hargraves, M., \& D enning, C. (2018). V isualizing expertise: Collaborative Pathway Modeling as a methodology for conveying community-driven strategies for change. Journal of A griaulture, Food Systems, and Community D evelopment, 8(Suppl. 1), 101-115. https:// doi.org/ 10.5304/ jafscd.2018.08A.005

Hoeft, T. J., Burke, W., Hopkins, S. E., Charles, W., Trinidad, S. B., James, R. D., \& Boyer, B. B. (2014). Building partnerships in community-based participatory research. $\mathrm{H}$ ealth Promotion Practio, 15(2), 263-270. https:/ / doi.org/ 10.1177/ 1524839913485962

Holt, S. (2015, September 22). Majoring in food: Colleges offering more courses, degrees; as the food movement grows, the demand for college and university classes focusing on food systems is overflowing [Blog post]. Civil E ats. Retrieved from http:/ / civileats.com/ 2015/ 09/ 22/ majoring-in-food-colleges-offering-more-courses-degrees/

Israel, B. A., Eng, E., Schulz, A. J., \& Parker, E. A. (2005). Introduction to methods in community-based participatory research for health. In B. A. Israel, E. Eng, A. J. Schulz, \& E. A. Parker (Eds.), M ethods in community-based participatory research for health (pp. 3-26). San Francisco: Jossey-Bass.

Israel, B. A., Schulz, A. J., Parker, E. A., Becker, A. B., Allen, A. J. I., \& G uzman, J. R. (2003). Critical issues in developing and following community based participatory research principles. In M. Minkler \& N. Wallerstein (Eds.), Community-based participatory research for health (pp. 53-79). San Francisco: Jossey-Bass.

Ledford, H. (2014). Indirect costs: Keeping the lights on. N ature, 515(7527), 326. https:/ / doi.org/ 10.1038/ 515326a

Minkler, M., Blackwell, A. G., Thompson, M., \& Tamir, H. (2003). Community-based participatory research: Implications for public health funding. A merican Journal of Public $\mathrm{H}$ ealth, 93(8), 1210-1213. https:// doi.org/ 10.2105/ AJPH.93.8.1210

Mitchell, M., Leachman, M., \& Masterson, K. (2016, August 15). Funding down, tuition up: State cuts to higher education threaten quality and affordability at public olleges Retrieved from https:/ / www.cbpp.org/ research/ state-budget-and-tax/ fundingdown-tuition-up

Rodríguez, D . (2007). The political logic of the non-profit industiral complex. In Incite! Women of Color Against Violence (Ed.), T he revolution will not be funded: Beyond the non-profit industrial complex (pp. 21-40). Cambridge, MA: South End Press.

Sequeria, E. J. \& Porter, C. M. (2015, December). Grow dignity, democracy, diversity to grow good* food systems (*resilient, ethical, triple sustainable). Presentation at the Enhancing Food Security in the Northeast (EFSNE) with Regional Food Systems Conference, Greenbelt, Maryland. Retrieved from https:/ / agsci.psu.edu/ research/ foodsecurity/ conference-materials/ files/ other-afris/ food-dignity-plenary-two

Uniform Administrative Requirements, Cost Principles, and Audit Requirements for Federal Awards, 2 C.F.R. § 200.75. (2014). Retrieved from https:/ / www.gpo.gov/ fdsys/ pkg/ CFR-2014-title2-vol1/ pdf/ CFR-2014-title2-vol1part200.pdf

U.S. D epartment of Agriculture [USD A] National Institute of Food and Agriculture [NIFA]. (2010). A griculture and F ood Research Initiative competitive grants program, global food seaurity: FY 2010 Request for A pplications. Washington, D .C.: USD A.

University of Wyoming O ffice of Academic Affairs and Budget O ffice. (2013). U niversity of W yoming budget primer. Retrieved from www.uwyo.edu/ acadaffairs/plans/ budget_primer_2013.pdf

Wallerstein, N., \& D uran, B. (2010). Community-based participatory research contributions to intervention research: The intersection of science and practice to improve health equity. A merican Journal of Public H ealth, 100(S1), S40-S46. https:// doi.org/ 10.2105/ ajph.2009.184036

Woodsum, G. M. (2018a). Entering into a community-university collaboration: Reflections from Feeding Laramie Valley. Journal of A griaulture, F ood Systems, and Community D evelopment, 8(Suppl. 1), 17-22. https:/ / doi.org/ 10.5304/ jafscd.2018.08A.017

Woodsum, G. M. (2018b). The cost of community-based action research: Examining research access and implementation through the Food Dignity project community support package. Journal of A griaulture, F ood Systems, and Community D evelopment, 8(Suppl. 1), 83-99. https:/ / doi.org/ 10.5304/ jafscd.2018.08A.021 